\title{
Assessment of establishment and operations under market conditions for a public equity fund
}

UDK: 338.246.027(045)

\author{
Jaka Vadnjal \\ Gea College, Visoka šola za podjetništvo \\ jaka.vadnjal@gea-college.si
}

\begin{abstract}
The government of Slovenia established a publicly funded venture capital fund in order to provide start-up finance for small companies. The fund was meant to fill in the market gap in early-stage equity finance supply. The fund is co-financed from EU structural funds and has to comply with strict regulation regarding possibility of market distortion from such measure. The objective of the study is to give a straightforward answer whether the public fund will behave within the equity market conditions or will impose an unloyal competition to the existing privately financed funds. In accordance to this, an evaluation is given advising that the public fund should not be regarded as a state-aid measure.

Key words: venture capital, SMEs, fund management company, state aid, market conditions

JEL: G24

\section{Introduction}

In 2008 the Government of Slovenia established a risk capital investment fund - Prva družba tveganega kapitala (thereinafter "PDTK") which was the first implication of the Law on venture capital companies (ZDTK) adopted in 2007. The objective of adopting the specialized law on venture capital was
\end{abstract}




\section{Jaka Vadnjal \\ Assessment of establishment and operations under market conditions for a public equity fund}

mainly to set up a legal framework for establishment of new venture capital firms, the purpose of the PDTK is to provide capital to SMEs which preferably have core competencies in technology and are in their start-up phase. The PDTK's focus are SMEs in key technology sectors of the Slovenian economy. The authorities hope that the measure will lower underlying financing risks and increase confidence in further financing, notably private-equity financing, thus to override the traditional finance gap evidenced in this sector (Chu \& Hisrich, 2001). While financing eligible activities, the measure is intended to increase the competitiveness and to strengthen the equity base of start-up SMEs (Baygan, 2003).

The activities that are to be financed with the capital provided by the PDTK are moreover research or pre-competitive technological development of new or improved products, processes or services. Eligible activities will be tailored to a recognized market demand and should be distinguished by particular know-how, if possible capable of having intellectual property rights protected (Hellman \& Puri, 2000). The mission of the PDTK is also to financially catalyze and stimulate the knowledge flow from research institutions to mostly SMEs, as an integrative element in the setup of support institutions, universities, research and technology parks, incubators and public agencies providing to SMEs (Botazzi \& Da Rin, 2002).

\section{Objectives of the study}

The PDTK and its investments are directly financed by public resources: (1) from the European Regional Development Fund (ERDF), (2) co-financing from the national budget of the Republic of Slovenia, and (3) from own resources of Slovenian Enterprise Fund (SEF), which is a public fund. The financing under the measure may improve the overall financial condition and enhance the market position of all stakeholders involved (Sunley et al., 2005). The measure does not rule out the award of aid to firms engaged in economic sectors where intra-Community trade takes place. Thus, the fund and its operations could constitute aid within the meaning of Article 87(1) EC. The assessment of this measure could fall within the scope of the Community Guidelines on State aid to promote risk capital investments in small and medium-sized enterprises (thereinafter "the Guidelines"). 


\section{Jaka Vadnjal \\ Assessment of establishment and operations under market conditions for a public equity fund}

For the Guidelines to be applicable the following conditions must be met: (1) the measure must be a scheme, targeting SMEs; (2) the measure must not be intended to provide capital to an individual enterprise; (3) the measure must exclude aid to enterprises in difficulty as defined in the Guidelines and, (4) the Guidelines do not apply to aid for export-related activities, namely aid directly linked to the quantities exported, to the establishment and operation of a distribution network or to other current expenditure linked to the export activity, as well as aid contingent upon the use of domestic in preference to imported goods. Thus, the planned measure falls in an unfavorable position of conflict between real market driven forces and bureaucratic establishment of rules that are set to defend market conditions (Lerner, 2002).

As defined within the scope of the Guidelines, financing for the setting-up and operation should only be provided at market conditions. According to this, there are certain issues which may be daubed whether they are eligible to be treated as market conditions (Farag et al., 2004): (1) how the fund management company would be selected, (2) what would be appropriate fund management remuneration, (3) expected rates of returns for the investment and (4) possibility for private sector co-investment. In accordance to this, the following questions were defined to be addressed and answered in the research:

Q1. Is there a fund management company in Slovenia which may be ready and competent to manage a publicly established risk capital fund according to the Guidelines and respecting ERDF rules?

Q2. What is the flat rate management fee, normally charged on comitted capital by the fund management companies operating in Slovenia and what is the market conditioned level of profit sharing fund for management remuneration?

Q3. What are the expected rates of return for risk and venture capital investments in the Slovenian market?

Q4. Is there any interest in private sector to invest in a publicly established fund or to co-invest alongside the fund's investment on the level of an individual company?

The present study should be therefore understood as more exploratory rather than confirmatory, thus no propositions and/or hypotheses are proposed. Instead, just a set of research questions is put forward. 


\section{Jaka Vadnjal \\ Assessment of establishment and operations under market conditions for a public equity fund}

\section{Literature overview}

While debt financing is the most important source of European enterprise finance over the past decade, alternative instruments can become a significant factor in providing flexibility and choices that better reflect the needs of enterprises throughout their development. Venture capital is likely to become the most important option for specific knowledge based and growth oriented types of SMEs.

The experience of venture capital in the USA shows that different forces call for an increasing share in venture capital financing, either in the form of (formal) venture capital funds, business angels or existing corporations through their capital venturing. Experts used to stress the "equity capital culture" when explaining the strength of venture capital in the USA and Great Britain (Cumming and Maclntosh, 2003). However, according to some empirical evidence (Ernst \& Young, 2006) it is not only a true entrepreneurial Anglo-Saxon culture but government support for this type of capital with appropriate regulation and tax policy that is needed. The U.S. government supported innovative SMEs through SBICs, tax-policy-preferred capital gains while, in 1978, pension funds were allowed to invest in venture capital funds (Gompers \& Lerner, 2002). Along with the "silent revolution" involving entrepreneurship and changes in technology, this support has seen growth in the amount of traditional venture capital from around USD 5 billion in the mid-1990s to growth for more than twenty times in ten years, with an even larger amount in informal investments (Bygrave et al., 2003). Venture capital has also developed a viable organizational structure of partnership management companies that are rewarded according to an investment's success. Europe expressed its commitment to risk capital as a reflection of its concern over the high level of SMEs' dependence on debt finance, as part of efforts to create an entrepreneurial Europe (Cosh \& Hughes, 2003). However, EU countries have trailed behind the development of venture capital in the USA (Romain and Van Pottelsberghe, 2003) and the economic slump in 2001-2002 seriously aggravated the situation in the venture capital market for both SMEs and VC funds (Kjaergaard \& Nordstrom, 2004). Yet, it can be assumed that following economic recovery venture capital will again become more important at least for certain types of SMEs or enterprises in certain stages of their existence (Hermann et al., 2004). This is very important since venture capital has backed those companies that have really made technology breakthroughs. The study of VC-backed firms in Europe 
Jaka Vadnjal

\section{Assessment of establishment and operations under market} conditions for a public equity fund

shows that venture capital was an essential ingredient of their creation, survival and growth, while $60 \%$ of these said they would not be in business today without the funding and support of venture capitalists (Mayer et al., 2001).

Slovenian banks and other investors as the supply side of venture capital started early in the entrepreneurship wave of 1990s, to become involved in some types of venture capital investment (Glas et al., 2002). However, problems arise more from the demand side and the lack of ambitious entrepreneurial projects. In addition, the legal, administrative and tax environment is not conducive to such investments. Because of the overall low development of capital markets, one of the main obstacles seems to be the lack of exit possibilities which make the venture capital market liquid and thus attractive for investors (Wright et al., 2005).

One of the sub-goals of the study is also to assess the market dynamics of equity financing. Demand and supply of venture capital is defined by three groups of factors (Schertler, 2003): (1) the level of entrepreneurial initiative of individuals, (2) innovation potential of the economic environment, with the resulting number of innovative ideas with ambition for entrepreneurial implementation and (3) institutional environment, making decisions on number and terms of financing innovative ideas. Saertre (2001) states, that it is a typical inductive research, where pattern builds on theoretical selection, being more desired and appropriate in comparison to coincidental selection, which is basis of deductive research. A "loose structured interview" is the most adequate format of collecting data, recommended in literature (Miles and Huberman, 1994). It enables a sufficient quantity of information for a quality development of theory and hypothesis (Andersen \& Bollerslev, 1997), as well on the field of financing with private equity, discussed in this research. However, it turns to be a great research challenge to try to measure and evaluate a phenomenon that hardly exists and to put efforts to predictions of further development. Thus, confirmation of existence of equity gap at the market with really small quantities appears to be problematic, which is consistent to some previous research (Freshwater et al., 2001).

Nevertheless, one of the objectives is to obtain certain quantitative estimations from the study. Numerically it is a small pattern, which is a conscious weakness of the study but is a direct consequence of researching a smallscale market. The paradigm that it is not appropriate to address quantitative research questions with qualitative methods (Davidsson, 2005) was consciously by-passed for this occasion since no better research solution was 


\section{Jaka Vadnjal \\ Assessment of establishment and operations under market conditions for a public equity fund}

available. As we have to deal with two theoretically different concepts, a preformulated content of the interview has been structured only for the part where we want to collect quantity data in order to make a rough estimate on the extent of demand and supply of equity capital.

\section{Methodology}

The methodology applied for this particular report generally consists of (1) descriptive analyses of secondary sources, revealed in the literature and sources section; (2) qualitative primary data and information analyses and; (3) benchmarking with the similar public venture capital fund established in another country, which has passed the identical procedure of proving the (non)compliancy with the EU state-aid measures. The primary data was compared and compiled from two collection processes. The first round took place in May and June 2006 (Vadnjal et al., 2006) and the second round was overtaken in February 2007.

The methodology of data collection was a semi-structured interview, held with several equity market players such as venture capital companies and fund management companies operating in Slovenia while also several banks, insurance companies and some larger corporations were invited to participate in the study (Megginson, 2004). The interviews were held with top representatives of the companies, thus it can be proposed that their opinions represent competent, true and fair reflection of the current market situation (Meyer, 2007). The Slovenian market is, as expected, specific for its limited scope, having low level of specialization in the finance intermediaries sector (Bruton \& Ahlstrom, 2003), which results in the fact that many industry players (apart from traditionally managed banks) are active in several financial sub-markets.

The participants in the study may be differentiated into three groups on the basis on their market position being: (1) fund management companies, or fund supplier institutions such as (2) financial holdings, banks, insurance companies etc., and (3) larger corporations. Several actors participating in the study may be wearing different hats, being both, the fund management company and financial company, or other combinations which may not be particularity of Slovenia (Mason, 1999). On the other hand, expressed limitations of the 
market do not put many research opportunities to go into some more in-depth quantitative research methodologies in order to get a more accurate evaluation of several market parameters, such as expected return rates, management fees, management remuneration (profit sharing option), etc. Another important limitation of the study is that the data was collected in the times which were still far away from the recession (before autumn 2008) which imposes the possibility that the attitudes of the respondents might be quite different in the light of the actual global economic crisis.

The following market actors in Slovenia participated in the study (some names repeat for mentioned reasons of being involved in different activities):

- As fund suppliers (16): NLB, Abanka, Banka Koper, Probanka, Poštna banka, Hranilnica Lon, Banka Celje, Reifeissen Krekova banka, NKBM (as banks), Zavarovalnica Triglav, Adriatic Slovenica, Prva pokojninska družba (as insurance companies), Poteza, KD Holding, Aktiva invest; Individa (as financial companies);

- As corporate investors (14): llirija, Mura, ETI, Blues, EMO orodjarna, Alpina, Petrol, Danfoss Trata, AC Cosmos, Kovinoplastika Lož, Brest, Litostroj; Krka, Gorenje;

- As fund management companies (11): Horizone Venture Management, Poteza, NLB Funds, Sivent, KD Holding, Ilirika, Taxgroup, Aktiva Invest, Perspektiva, Individa, RSG fund.

\section{Key findings}

Key findings relevant to the raised issues in the objectives of the study are in the fields of (1) fund management where selection of the fund management company is considered and remuneration of the management company is discussed; (2) expected rates of returns for the funds and, (3) public involvement in the PDTK's investment activities. 


\section{Jaka Vadnjal \\ Assessment of establishment and operations under market conditions for a public equity fund}

\subsection{Fund management}

There are two questions which were identified regarding the possible consideration of the market conditions of the PDTK's operations. According to Guidelines, also the service providers within the investment process should be expected to behave strictly under market conditions. For this particular reason, selection procedures are examined together with service price (i.e. fund management remuneration).

\subsubsection{Selection of the fund management company}

The management company was not selected by a public tender procedure. From the comparative study of the other potential fund management companies mentioned above it could be concluded that the fund management company established by the government is the only company in Slovenia, having the human resource potential available, that has the expertise to manage funds with ERDF co-financing in strict compliance with EC and domestic regulation. Moreover, the general opinion of the benchmarked management companies was that they would not be interested in the future to manage schemes falling under "too demanding administrative and legal procedures". In the table 1, there is a summary of the interpreted answers to this research question.

Table 1. Interest to manage a public fund

Q1: Do you have interest and competencies to manage a publicly established and financed risk capital fund?

\begin{tabular}{|c|c|c|c|c|}
\hline \multirow{2}{*}{ Yes } & \multirow{2}{*}{ Maybe } & \multicolumn{2}{|c|}{ No } & \multirow{2}{*}{ Total } \\
\cline { 3 - 4 } & & Not interested & Not competent & \\
\hline 0 & 1 & 4 & 6 & 11 \\
\hline
\end{tabular}

Source: Own research 2006-2008

The evaluation of the management capabilities available in the region was also done. The companies focused on the region as they consider proximity to be vital for managing funds of that size and scope, given the need for intensive monitoring and supervision of the target enterprises. The evaluation pointed out that there was no fund management company with a track record of managing 
EU funds. Furthermore, the existing fund management companies (1) were mostly established to manage internally created and raised funds, (2) there was actually only a branch office for Slovenia, or (3) might be temporary out of business for certain legal reasons. As far as competences were concerned, the vast majority of respondents admitted not to have any experience with EU funding prerequisites but they generally shared impression that a bulk of bureaucratic procedures had to be dealt with in such cases, thus implying requirements for additional and for the time being non-existing human resources in order to manage such a fund.

\subsubsection{Fund management remuneration}

Remuneration of the managing company is normally expected to consist of two components. Firstly, the managing company will receive $2.5 \%$ of the committed capital annually as management fee, during the six-year investment phase. Secondly, after the investment phase ends, the variable part of the management fee will be calculated based on the capital invested less the costs. The second phase is paid after the completion of the investment phase on the level of each particular project (i.e. invested company). The costs are located proportionally to committed capital into a particular investment. Three investigated fund management companies expected the fees to be around 20 $\%$, which is also EVCA's (2009) recommendation. Other participants in the study whether regarded this information as confidential or did not provide any clear answer. Having in mind the limited availability of trustworthy research data and information, it is confirmed that $20 \%$ shares on profit by the management company is a market conditioned expected variable part of the fund management remuneration. In the table 2, there is an analysis of participant's answers regarding the management fee, while in table 3 the views regarding the profit-sharing fees are described.

Table 2. Management fee rate

Q2: What is the fee rate on the committed capital that you normal charge for similar fund management assignments?

\begin{tabular}{|c|c|c|c|c|}
\hline $2.5 \%$ & Around $2.5 \%$ & $\begin{array}{c}\text { Classified } \\
\text { information }\end{array}$ & No answer & Total \\
\hline 6 & 3 & 2 & 0 & 11 \\
\hline
\end{tabular}

Source: Own research 2006-2008 


\section{Jaka Vadnjal \\ Assessment of establishment and operations under market conditions for a public equity fund}

The remuneration principles, as presented, do reflect market rates, taking into account the limitations of Slovenian market and its development phase, which can be evaluated as early enough for many of study respondents to express mere their expectations from possible future deals rather than actually achieved and collected management fee rates. The other possibility is also that the expressed $2.5 \%$ fee rate is expressed through following EVCA's (2009) recommendations. The two respondents which did not want to reveal information regarding the management fee rate (1) were a foreign branch office of a larger fund operating all over Europe and (2) a company which was established on purpose to manage a particular fund.

\section{Table 3. Management profit-sharing rate}

Q3: What is profit-sharing fee rate that you normal charge for similar fund management assignments?

\begin{tabular}{|c|c|c|c|c|}
\hline $20 \%$ & Around $20 \%$ & $\begin{array}{c}\text { Classified } \\
\text { information }\end{array}$ & No answer & Total \\
\hline 2 & 2 & 1 & 6 & 11 \\
\hline
\end{tabular}

Source: Own research 2006-2008

\subsection{Expected rate of returns}

The evaluation of expected rate of returns on the level of an individual investment is a demanding assignment. The research among fund suppliers (Vadnjal et al., 2006) may impose a speculation that possible fund suppliers may not have a very clear picture on preferable or expected return rate. The articulated rate can be summed up to be "at least $20 \%$ " which is on the other side often achieved even in the mutual funds industry in which majority of the potential fund providers also operate. In the table 4, data on expected rates of return are elaborated in detail. It can be observed that this opinion was provided by four study participants while others did not answer anything. 
Table 4. Expected rate of return

Q4: What is your expected rate of return when investing into start-ups?

\begin{tabular}{|c|c|c|c|c|}
\hline $20 \%$ & At least $20 \%$ & $\begin{array}{c}\text { Classified } \\
\text { information }\end{array}$ & No answer & Total \\
\hline 0 & 4 & 0 & 7 & 11 \\
\hline
\end{tabular}

Source: Own research 2006-2008

On the other hand, the research has been made in the times of positive trends on Slovenian stock exchange markets which consequently make mutual funds industry highly attractive for massive in-flows of cash. Therefore, the expected return rates for more risky venture capital investments may be higher. However, this might change rapidly in the case of downturn of the stock exchange ratios. In this case, lower expected return rates for venture and risk funds are expected. Since the data for this study were collected far before the 2008-09 recession, it is correct to give a brief comment in the light of the financial crisis. One can say that it has affected the venture capital industry like all other businesses. Fund-raising has become extremely hard and investment managers are more cautious. As there have been hardly any activities in the 2009, it can be stated that the crisis would seriously affect the findings if the research would have been undertaken in some later stage of the crisis.

\subsection{Private sector investments}

There were options of private sector direct or indirect investment involvement assessing: (1) direct investments from the private sector into the fund managed by PDTK and (2) potential co-investments in the targeted SMEs. The elaborated data on the potential interest to invest into the PDTK's fund is available in the table 5, while the alternative option to co-invest on the level of individual company is explored in the table 6. 
Jaka Vadnjal

Assessment of establishment and operations under market conditions for a public equity fund

Table 5. Interest for investments into PDTK

Q5: Would you be interested to invest directly into PDTK's fund?

\begin{tabular}{|l|c|c|c|c|}
\hline & Yes & Maybe & Not at all & Total \\
\hline Financial inst. & 0 & 2 & 14 & 16 \\
\hline Corporations & 0 & 0 & 14 & 14 \\
\hline Total & 0 & 0 & 28 & 30 \\
\hline
\end{tabular}

Source: Own research 2006-2008

Concerning the direct investment into the fund the study participants expressed high level of aversion regarding this investment option. The following reasons for practically nil interest were expressed:

- High risk, combined with low rates of return, as compared to other investment opportunities (management-buy-outs/buy-ins, private equity placements etc.):

- High monitoring and supervision costs which means high overhead and sunk costs in comparison to the volume and quantity of the funds;

- The limited investment opportunities because of the preferences for geographical proximity of invested companies;

- Relatively low management fees, due to the small average volume of transactions;

- Moderate level of experience and expertise regarding more risky investments and direct ownership involvement in the companies;

- Funds prefer to keep the due diligence processes under their own control;

- They insist to keep management and supervision of investments within their own management companies; 
Jaka Vadnjal

\section{Assessment of establishment and operations under market} conditions for a public equity fund

- Financial intermediaries which are active in several different capital market segments prefer to remain flexible and not to lock their resources only into venture capital activities because of possible better opportunities in other sub-markets (for instance mutual funds);

- Some intermediaries (like banks and insurance companies) face serious legislative barriers and limitations which prevent them from getting involved into riskier financial investments.

Based on this evaluation, it can be stated that a clear market failure is present at the market segment on which the PDTK operates and that the PDTK does not offer satisfactory investment or co-investment opportunities for private investors. Moreover, there is perceived almost no interest among private investors to participate at the level of the PDTK. However, there is some interest for the involvement at the level of each transaction, alongside the PDTK operations. Interestingly, in the same time period (2006-2008), two banks have already decided to invest in privately established and managed venture capital fund.

Several interviews were conducted also with larger companies that may in the future provide some capital with a clear objective to foster development of spin-off companies, which may increase the research and development potential of the core business. However, this is the concept that has not reached its maturity in Slovenia yet. Out of the 14 explored investment companies (listed above), none of them expressed any interest to invest into the publicly established fund, nor considered any equity investments or coinvestments in new start-ups or spin-offs.

Table 6. Interest for co-investments on the individual company level

Q6: Would you be interested to co-invest with PDTK into individual company?

\begin{tabular}{|l|c|c|c|c|}
\hline & Yes & Maybe & Not at all & Total \\
\hline Financial inst. & 12 & 2 & 2 & 16 \\
\hline Corporations & 2 & 2 & 10 & 14 \\
\hline Total & 14 & 4 & 12 & 30 \\
\hline
\end{tabular}

Source: Own research 2006-2008 


\section{Jaka Vadnjal \\ Assessment of establishment and operations under market conditions for a public equity fund}

\section{Conclusions and recommendations}

At the time being there is no fund management company operating in Slovenia, which would be evaluated to possess competencies and interest to manage publicly funded risk capital fund. The government of Slovenia should therefore proceed with the activities to provide its own venture fund management company PDTK with sufficient both financial and other necessary resources. It would be highly recommendable for PDTK to pull together a network of experts in order to provide expertise and assistance in the investment decision-making processes. This pool of experts should not be limited to Slovenian based specialists but should involve at least European if not global business perspective. There is a need to underpin again that Slovenian risk and venture capital market is far from the point of being regarded as developed (only between 28 and 30 investments done so far, only two exits in twelve years), thus making these estimations very robust and conditioned with only limited quantity of data and information.

The market conditioned management fee rate is $2.5 \%$ in Slovenia and the profit sharing fee is $20 \%$ of the profits realized. The PDTK should include the business rates mentioned above in their business plan. Thus, speaking about market conditioned internal rate of return on investment risk capital and venture capital investment is at least $20 \%$. Project proposals with projected returns below $20 \%$ on year basis should be directed out of the PDTK's pipeline and further due diligence process.

There is no interest from private sector in Slovenia to invest in the PDTK's fund. On the other side, there is some interest in private sector to go into syndicated investments together with PDTK. PDTK should develop a sustainable system to attract co-investment on the company level from the private sector. However, there may always remain a certain degree of reluctance towards this type of private-public investments because of the possible fear of government's and politically motivated interventions with regard to the business.

The Community Guidelines on State aid to promote risk capital investments in SMEs enforce that financing for the start-up and operation should only be provided at market conditions. Several issues which maybe impose dilemmas whether they can be treated as market conditions were overviewed in this study: (1) selection of the fund management company; (2) fund management remuneration; (3) expected rates of returns and 


\section{Jaka Vadnjal \\ Assessment of establishment and operations under market conditions for a public equity fund}

(4) private sector co-investment. The following recommendations may be put forward:

- As far as the selection of the fund is concerned, the supply of competent service provider which would also have experience with cofinancing arrangements through ERDF fund does not exist. Therefore, the need for existence of a publicly owned management company which fills in the gap is supported.

- Regarding the management remuneration it can be stated that $2.5 \%$ management fee on the capital committed is the market conditioned charge. There is less evidence to support $20 \%$ profit sharing remuneration. However, these findings should be trusted to be accurate in the given situation within the scope of the data and information available.

- As far as expected rates of return are concerned, the evidence and experience is Slovenia is poor and offers not much spare room for possible elaboration. However, the bottom rate of $20 \%$ is rate advised to the PDTK's fund management and supervisors.

- Lastly, the fund management can only thrive for private co-investment on the level of individual company. By no means there is any evidence on any potential interest from potential fund suppliers to invest in the publicly established venture capital fund. On the other hand, there is a certain interest in private sector to go for syndicate investment with the PDTK. This interest is widely expressed by financial institutions while it is less evident among corporations.

The possible implications of the paper are needed to be discussed with caution. First, the doubt about methodological issue remains present with the main dilemma: if more sophisticated techniques were used, would this increase the reliability of the results. It has been a repeated issue of researching something that is hard to research because of small scope or due to the phenomena never researched so far (Da Rin et al., 2006). Thus, the more sophisticated methods would not diminish the doubtfulness of the results, probably the most serious limitations of the study. 


\section{Jaka Vadnjal Assessment of establishment and operations under market conditions for a public equity fund}

Dr. Jaka Vadnjal graduated from mechanical engineering, mastered from entrepreneurship and holds Ph. D., all from University of Ljubljana, Slovenia. He is senior lecturer at GEA College of Entrepreneurship, where he also serves as director of the research institute and president of the senate. He has been teaching at GEA College since 1996 and managed and participated in several research projects. He presented papers at several conferences worldwide. He authored and co-authored eleven original scientific articles published in journals. The papers and articles cover topics in family business and venture capital. He is also co-author of four books on entrepreneurship also published outside Slovenia.

\section{Literature and sources}

- Andersen, T. G., \& Bollerslev, T. 1997. Heterogeneous information arrivals and return volatility dynamics: uncovering the long-run in high frequency returns. Journal of Finance 52 (3), 975-1005.

- Baygan, G. 2003. Venture capital policy review: United Kingdom. STI Working Paper 2003/1. Pariz: OECD.

- Botazzi, L., \& Da Rin, M. 2002. Venture capital in Europe and financing of innovative companies. Economic Policy 17 (34), 229-270.

- $\quad$ Breuss, F., Fink, G. \& Haiss, P. 2004. How well prepared are the new member states for the European monetary union? Journal of Policy Modeling 26 (7): 769-791.

- Bruton, G. D., \& Ahlstrom, D. 2003. An institutional view of China's venture capital industry: explaining the differences between China and the West. Journal of Business Venturing 18 (2), 233-259.

- $\quad$ Bygrave, W. D., Hay, M., Ng, E., \& Reynolds, Reynolds, P. D. 2003. Executive forum: a study of informal investing in 29 nations composing the Global Entrepreneurship Monitor. Venture Capital: An International Journal of Entrepreneurial Finance 5 (2), 101-116.

- Chu, P., \& Hisrich, R. D. 2001. Venture capital in an economy in transition. Venture Capital 3 (2), 169-182

- Cosh, A., \& Hughes, A. 2003. Enterprise challenged: policy and performance in the British SME sector 1999-2002. University of Cambridge: ESRC Centre of Business Research.

- Cumming, D. J., \& MacIntosh J. G. 2003. A cross-county comparison of full and partial venture capital exits. Journal of Banking and Finance 27 (3), 511-548 


\section{Jaka Vadnjal \\ Assessment of establishment and operations under market conditions for a public equity fund}

- Davidsson, P. 2005. Researching entrepreneurship. New York: Springer.

- Da Rin, M., Nicodano, G., \& Sembenelli, A. 2006. Public policy and the creation of active venture capital markets. Journal of Public Economics 90 (8-9), 1699-1723.

- $\quad$ Ernst \& Young. 2006. Transition global venture capital insights report.

- European Comission. 2009. Handbook on community state aid rules for SMEs including temporary state aid measures to support access to finance in the current financial and economic crisis. Retrieved from: http://ec.europa.eu/competition/ state_aid/studies_reports/sme_handbook.pdf.

- EVCA. 2009. EVCA Reporting Guidelines June 2006 Reprint January 2009. Retrieved from: http://www.evca.eu/uploadedFiles/Home/Toolbox/Industry_Standards/ evca_reporting_guidelines_2009.pdf.

- Farag, H., Hommel U., Witt P., \& Wright M. 2004. Contracting, monitoring and exiting venture investments in transitioning economies: a comparative analysis of eastern European and German markets. Venture Capital: An International Journal of Entrepreneurial Finance 6 (4), 257-282.

- $\quad$ Freshwater, D., Barkley, D. L., Markley, D. M., Sass Rubin, J., \& Shaffer, R. 2001. Non traditional venture capital institutions: Filling a financial market gap. Columbia: Rural Policy Research Institute.

- Glas, M., Drnovšek, M., \& Pšeničny, V. 2002. Is private equity capital really the solution? V: Research in Entrepreneurship and Government Policy: Making the Connection. Vlerick Leuven Gent Management School.

- Gompers, P., \& Lerner, J. 2001. The venture capital revolution. Journal of Economic Perspectives 15 (2), 145-168.

- Hellman, T., \& Puri, M. 2000. The interaction between product market and financing strategy: the role of venture capital. Review of Financial Studies 13 (4), 959-984.

- Hermann, H., Liebig, T., \& Tödter. K. H. 2004. Studies of economic research centre no. 18/2004. Frankfurt am Main: Deutsche Bundesbank.

- $\quad$ Kjaergaard, R., \& Nordstrom, B. J. 2004. Venture capital in Denmark. Copenhagen: Danish investment Fund (DIF).

- Klonowski, D. 2005. The evolution of the venture capital industry in transition economies: the case of Poland. Post-Communist Economies 17 (3), 331-348.

- Lerner, J. 2002. When bureaucrats meet entrepreneurs: the design of effective žpublic venture capital' programmes. The Economic Journal 112 (477), F73-F84. 
Jaka Vadnjal

Assessment of establishment and operations under market conditions for a public equity fund

- Mason, C. 1999. Editorial. Venture capital: rationale, aims and scope. Venture Capital 1 (1), $1-46$

- Megginson, W. L. 2004. Toward a global model of venture capital? Journal of applied corporate finance 16 (1): 89-107.

- Mayer, C., Schoors, K., \& Yafeh, Y. 2001. Sources of Funds and Investment Strategies of Venture Capital Funds, Evidence from Germany, Israel, Japan and UK. NBER Working Paper 9645.

- Meyer, K. E. 2007. Foreign direct investment in the early years of economic transition: a survey. Economics of Transition 3 (3), 301-320.

- Miles, M. B., \& Huberman, A. M. 1994. Qualitative data analysis: an expanded sourcebook. London: Sage.

- Romain, A., \& van Pottelsberghe, B. 2003. The determinants of venture capital: a panel data analysis of 16 OECD countries. Hitotshubashi University: Institute of Innovation Research, WP 03-25.

- Saetre, A. S. 2001. The demand side of the informal venture capital market: four Norwegian cases. Oslo: The Norwegian university of science and technology, Department of industrial economics and technology management.

- Schertler, A. 2003. Driving forces of venture capital investments in Europe: A dynamic panel data analysis. Kiel: Institute for world economics, working paper No. 03-27.

- Sunley, P., Klagge, B., Berndt, A., \& Martin, R. 2005. Venture capital programs in the UK and Germany: in what sense a regional problem? Regional Studies 39 (2), 255-273.

- Vadnjal, J., Berginc, J., Letonja, M., Penca, P., Slavnič, N., Palčič, I., \& Kerec, M. 2006. Študija o obstoju vrzeli lastniškega kapitala v Sloveniji. Piran: GEA College - Visoka šola za podjetništvo.

- Wright, M., Pruthi, S., \& Lockett, A. 2005. International venture capital research: from cross-country comparisons to crossing borders. International Journal of Management Reviews 7 (3), 135-165. 


\section{POVZETEK}

\section{PRESOJA USTANOVITVE IN DELOVANJA JAVNEGA SKLADA TVEGANEGA KAPITALA POD TRŽNIMI POGOJI}

\section{Uvod}

Slovenska vlada je leta 2008 ustanovila Prvo družbo tveganega kapitala (PDTK). Družba naj bi z javnim denarjem zapolnjevala tržno nišo v lastniškem financiranju malih in srednjih podjetij (MSP) in predvsem podjetniških zagonov. Družba je bila ustanovljena po Zakonu o družbah tveganega kapitala (ZDTK), ki ga je Slovenija sprejela 2007. PDTK naj bi se usmerila predvsem $v$ visokotehnološka podjetja s potencialom doseganja visoke dodane vrednosti in hitre rasti ter vstopa na mednarodne in globalne trge. PDTK ima za poslanstvo tudi spodbujanje trženja znanja, ki je plod razvoja in raziskovanja $v$ raziskovalnih institucijah, na univerzah, $v$ tehnoloških parkih in podjetniških inkubatorjih.

\section{Namen študije}

Načrtovano je, da se bo PDTK financiral iz javnih virov in sicer delno iz slovenskega nacionalnega proračuna in delno iz evropskih strukturnih skladov. Kot tak mora delovati $v$ skladu z evropsko regulativo in navodili evropske skupnosti glede obravnavanja javno financiranih skladov tveganega kapitala $v$ kontekstu državnih pomoči. Če javno financirani sklad lastniškega financiranja dobi status javne pomoči, lahko njegovo delovanje postane izjemno težavno in posledično manj učinkovito. Zato se države, ki organizirajo podobne finančne instrumente, skušajo izogniti statusu državne pomoči za svoje sklade. Seveda je to mogoče le, če dokažejo, da tudi javni skladi tveganega kapitala delujejo po tržnih zakonitostih in niso nelojalna konkurenca zasebnim skladom. Kriteriji presoje, ali državni sklad deluje po tržnih zakonitostih, ki jih skušamo preveriti tudi v pričujoči študiji, so predvsem: (1) kako bo izbrana družba, ki bo upravljala s skladom, (2) kakšna bo ustrezna nagrada za upravljanje sklada, (3)kakšni so pričakovani donosi na investirana sredstva in (4) možnosti soinvestiranja zasebnega sektorja. $\vee$ zvezi s tem so bila za študijo postavljena naslednja raziskovalna vprašanja: 
Jaka Vadnjal

Assessment of establishment and operations under market

conditions for a public equity fund

Q1. Ali v Sloveniji obstaja upravljalska družba, ki bi bila sposobna upravljati tak sklad $v$ skladu z evropskimi pravili o državnih pomočeh in Evropskega sklada za regionalni razvoj?

Q2. Kakšna je fiksna provizija kot delež investiranega kapitala za nagrade menedžmentu in kakšen je pričakovani odstotek upravljalske družbe pri delitvi dobička?

Q3. Kakšni so pričakovani donosi za javni sklad tveganega kapitala?

Q4. Ali v zasebnem finančnem sektorju obstaja interes za soinvestiranje $v$ javni sklad tveganega kapitala?

\section{Pregled literature}

Lastniško financiranje je $v$ Evropi manj prisotno $v$ podjetniški kulturi kot na primer $\vee$ ZDA (Cumming and MacIntosh, 2003), vendar so poskusi spodbujanja lastniškega financiranja prisotni povsod $v$ razvitejših in tudi tranzicijskih gospodarstvih (Gompers \& Lerner, 2002). Čeprav Evropa glede lastniškega financiranja še zelo zaostaja za ZDA (Romain and Van Pottelsberghe, 2003), prav $v$ razvoju lastniškega financiranja mnogi avtorji vidijo prebujenje podjetniške Evrope (Cosh \& Hughes, 2003). Seveda je tvegani kapital primeren samo za natančno določen in relativno ozek segment podjetij, ki so se s svojo inovativno podmeno odločila za hitro rast (Hermann et al., 2004; Mayer et al., 2001). V Sloveniji začetki tveganega kapitala segajo $v$ sredino devetdesetih let prejšnjega stoletja (Glas et al., 2002), vendar pravega razvoja doslej ni bilo, kar je pripisati predvsem majhnosti trga in posledično nizki likvidnosti kapitalskih trgov (Wright et al., 2005).

\section{Metodologija}

Metodologija študije sestoji iz treh delov: (1) deskriptivne analize sekundarnih virov, (2) kvalitativne analize primernih virov in (3) primerjave s podobnimi javnimi skladi tveganega kapitala $v$ drugih deželah, ki so se ravno tako ukvarjali z vprašanji državnih pomoči. Primarni podatki so bili zbrani $\vee$ dveh krogih (Vadnjal et al., 2006). Ključna metodologija 
Jaka Vadnjal

Assessment of establishment and operations under market conditions for a public equity fund

zbiranja primarnih podatkov je bil pol-strukturirani intervju, $\mathrm{h}$ kateremu so bile povabljene banke, zavarovalnice, družbe za upravljanje in tudi večja podjetja (Megginson, 2004). Intervjuvani so bili najvišji predstavniki teh inštitucij, pristojni, da izražajo resnične namere določene družbe (Meyer, 2007). Pri tem se je kot omejitev pokazala nizka stopnja specializacije $v$ sektorju finančnega posredništva (Bruton \& Ahlstrom, 2003), kar se kaže v tem, da mnogi igralci igrajo različne vloge $v$ finančnih tokovih.

$\checkmark$ raziskavi so sodelovale naslednje inštitucije (nekatera imena se zaradi vpletenosti $v$ različne procese pojavljajo več kot enkrat):

- Inštitucije, ki zagotavljajo sredstva (16): NLB, Abanka, Banka Koper, Probanka, Poštna banka, Hranilnica Lon, Banka Celje, Reifeissen Krekova banka, NKBM (kot banke), Zavarovalnica Triglav, Adriatic Slovenica, Prva pokojninska družba (kot zavarovalnice), Poteza, KD Holding, Aktiva invest; Individa (kot finančne družbe);

- Korporacijski investitorji (14): Ilirija, Mura, ETI, Blues, EMO orodjarna, Alpina, Petrol, Danfoss Trata, AC Cosmos, Kovinoplastika Lož, Brest, Litostroj; Krka, Gorenje;

- Firme za upravljanje skladov (11): Horizone Venture Management, Poteza, NLB Funds, Sivent, KD Holding, llirika, Taxgroup, Aktiva Invest, Perspektiva, Individa, RSG sklad.

\section{Ključne ugotovitve}

Prvo raziskovalno vprašanje se ukvarja z možnostjo, da se upravljalsko družbo izbere z javnim razpisom. Med potencialnimi kandidati ni niti ena upravljalska družba eksplicitno izrazila interesa za upravljanje z javnim skladom tveganega kapitala. Velika večina jih meni, da niso usposobljeni za upravljanje takega sklada zaradi preveč zahtevnih administrativnih postopkov $v$ zvezi z državnimi pomočmi in zahtevami strukturnih skladov. Kljub temu se je večina morebitnih upravljalskih družb strinjala z $2.5 \%$ upravljalsko provizijo, $20 \%$ udeležbo na dobičku po končani investiciji in pričakovanimi donosi $20 \%$ na letni ravni.

Vprašanje glede pričakovanih donosov na investicijo je pokazalo, da je med morebitnimi družbami za upravljanje le malo izkušenj in znanja, saj jih velika večina na vprašanje sploh ni odgovorila. Zato so verjetno pri izraženem mnenju o $20 \%$ pričakovanih donosih sledili priporočilom EVCA. 
Jaka Vadnjal

Assessment of establishment and operations under market

conditions for a public equity fund

Za soinvestiranje zasebnega sektorja $v$ javni sklad praktično ni interesa. Med razlogi za tako prevladujoče stališče najdemo visoko tveganje, visoke stroške monitoringa in nadzora, zelo omejene možnosti financiranja zaradi omejenega geografskega prostora, relativno nizke upravljalske provizije, malo izkušenj pri upravljanju tveganih investicij in željo po samostojnem opravljanju skrbnih pregledov. Zaradi vsega naštetega lahko trdimo, da na področju upravljanja sklada tveganega kapitala obstaja napaka trga, kar pomeni, da bo država morala nadaljevati z aktivnostmi ustanavljanja in zagona lastne družbe za upravljanje.

\section{Zaključki in priporočila}

V Sloveniji trenutno ni upravljalske družbe, ki bi bila spodobna upravljati javno financirani sklad tveganega kapitala ob upoštevanju zahtev sheme državne pomoči in zahtev evropskih strukturnih skladov. Tržno pogojeno nagrado za upravljanje sredstev bi lahko opredelili kot $2.5 \%$ na investirana sredstva, pri čemer upravljalske družbe pričakujejo tudi $20 \%$ udeležbo na dobičku. Pričakovani donosi na investirana sredstva se v pogojih tveganega financiranja gibljejo od $20 \%$ letno navzgor. Od zasebnega sektorja ni bilo zaznati interesa za soinvestiranje $v$ javni sklad tveganega kapitala. Koristno bi torej bilo, da država nadaljuje z zagonom lastne družbe za upravljanje, ki bo po eni strani delovala skladno s tržnimi pogoji in po drugi strani zagotavljala kompetence pri izvajanju zahtev strukturnih skladov in državnih pomoči. Zaradi majhnosti obsega raziskave ostaja odprta tudi metodološka dilema o ustreznosti raziskovanja neraziskanega (Da Rin et al., 2006), kar lahko komentiramo tudi s tem, da tudi bolj sofisticirane metode, kot jih uporabljamo $v$ študiji, ne bi odpravile dvoma $v$ zanesljivost rezultatov in ugotovitev. 